Beata Jeżyńska

\title{
Wspólnotowa typologia gospodarstw rolnych. Zagadnienia wybrane
}

\section{Uwagi wprowadzające}

Wspólna polityka rolna wdrożyła rozbudowany system instrumentów rynkowych i strukturalnych wspierających rozwój obszarów wiejskich oraz funkcjonujących na tych obszarach gospodarstw rolnych. Ocena skuteczności oraz adekwatności podejmowanych działań, przy uwzględnieniu zróżnicowanych celów, jakie realizowane mają być w ramach wspólnej polityki rolnej, wymaga stałego gromadzenia danych rynkowych oraz monitoringu zjawisk gospodarczych, środowiskowych, a nawet społecznych, jakie mają miejsce w sferze działalności rolniczej prowadzonej w poszczególnych krajach członkowskich UE. Niezbędnym przeto okazało się wprowadzenie jednolitego systemu badania i oceny kondycji gospodarstw rolnych oraz odpowiedniego ich klasyfikowania. Zasady klasyfikacji gospodarstw rolnych ${ }^{1}$ zostały określone decyzją Komisji (EWG) nr 85/377/EWG z dnia 7 czerwca 1985 r., ustanawiającą wspólnotową typologię gospodarstw rolnych ${ }^{2}$. Zasady określone w powołanej decyzji obowiązują do końca roku 2009, zaś począwszy od dnia 1 stycznia 2010 r. klasyfikacja gospodarstw rolnych dokonywana będzie według nowych założeń, stosownie do postanowień określonych w rozporządzeniu Komisji (WE) nr 1242/2008 z dnia 8 grudnia 2008 r., ustanawiającego wspólnotowa typologię gospodarstw rolnych ${ }^{3}$.

\section{Klasyfikacja gospodarstw rolnych w postanowieniach decyzji Komisji nr 85/377/EWG}

\subsection{Kryteria klasyfikacji}

Według zasad ustalonych w decyzji nr 85/377/EWG, gospodarstwa rolne funkcjonujące na terenie Wspólnoty klasyfikowane są w dwóch podstawowych katego-

$Z$ ang. The Community Typology of Agricultural Holdings.

Dz.Urz. WE L 220 z 17.8.1985, s. 1.

Dz.Urz. UE L 335 z 13.12.2008, s. 3. 
riach - wielkości ekonomicznej oraz typu rolniczego ${ }^{4}$. Klasyfikacja obu kategorii dokonywana jest według kryterium ekonomicznego. Głównym parametrem wykorzystywanym we wspólnotowej typologii gospodarstw rolnych jest standardowa nadwyżka bezpośrednia. Podstawą do jej obliczenia jest nadwyżka bezpośrednia.

Nadwyżka bezpośrednia (Gross Margin) z określonej działalności rolniczej, obliczana zgodnie z metodologią wspólnotową, to roczna wartość produkcji, uzyskana z jednego hektara uprawy lub od jednego zwierzęcia, pomniejszona o koszty bezpośrednie poniesione na wytworzenie tej produkcji. Wytyczne Komisji definiują strukturę wartości produkcji oraz kosztów w rachunku nadwyżki bezpośredniej. I tak, wartość produkcji określonej działalności produkcji roślinnej lub zwierzęcej jest sumą wartości produkcji podstawowej oraz produkcji drugorzędnej wprowadzonej do obrotu rynkowego i określana jest według cen sprzedaży na terenie gospodarstwa. Do wartości produkcji doliczane są dotacje do produktów lub do zwierząt, a odejmowane poniesione straty.

Zestaw kosztów bezpośrednich, o które obniżana jest wartość produkcji, jest odmienny dla działalności roślinnej ${ }^{5}$ i zwierzęcej ${ }^{6}$, ale w obu przypadkach musi odzwierciedlać bieżące warunki rynkowe. Podstawą zaliczenia określonych wydatków do kosztów bezpośrednich jest jednoczesne spełnienie trzech warunków. Przede wszystkim koszty objęte odliczeniem można bez żadnych wątpliwości przypisać do określonej działalności; ich wielkość ma proporcjonalny związek ze skalą produkcji; a nadto, mają bezpośredni wpływ na rozmiar (wielkość i wartość) produkcji. Poszczególne składniki kosztów są pomniejszane o przyznane dotacje. Kwoty należnego lub naliczonego podatku od towarów i usług (VAT) nie są uwzględniane przy wyliczeniu nadwyżki bezpośredniej ${ }^{\top}$.

Standardowa nadwyżka bezpośrednia (Standard Gross Margin - SGM) jest nadwyżką średniej z trzech lat wartości produkcji określonej działalności rolniczej, nad średnią z trzech lat wartością kosztów bezpośrednich, w przeciętnych dla dane-

Klasyfikacja gospodarstw rolnych, traktowanych jako ich podział na odpowiednie grupy, bywa także dokonywana według innych, bardziej szczegółowych kryteriów, takich jak: kryterium ilościowe, czyli zasoby ziemi, kryterium kierunku produkcji określanego według dalszych kryteriów - naturalnych i wartościowych. Dokonywane tak podziały nie mają charakteru uniwersalnego i są wykorzystywane przede wszystkim do wydzielenia gospodarstw jedno-, dwu- lub wielokierunkowych. Szerzej zob. A. Skarżyńska, L. Goraj, I. Ziętek, Metodologia SGM „2002” dla typologii gospodarstw rolnych w Polsce, Warszawa 2005, s. 20 i nast.

5 Do kosztów bezpośrednich produkcji roślinnej zalicza się: materiał siewny i nasadzeniowy, zakupione nawozy, środki ochrony roślin, regulatory wzrostu, ubezpieczenia danej działalności oraz koszty specjalistyczne, tj. specjalistyczne wydatki na produkcję, usługi specjalistyczne oraz najem dorywczy do prac specjalistycznych. Zob. A. Skarżyńska, L. Goraj, I. Ziętek, Metodologia SGM..., s. 24.

6 Do kosztów bezpośrednich produkcji zwierzęcej zalicza się: zwierzęta wchodzące do poszczególnych działalności w celu wymiany stada, pasze, czynsze dzierżawne za użytkowanie powierzchni paszowej wydzierżawione na okres krótszy od jednego roku (np. hale górskie), ubezpieczenie zwierząt, lekarstwa i środki weterynaryjne, usługi weterynaryjne, koszty specjalistyczne - na produkcję zwierzęca, usługi oraz najem dorywczy do prac specjalistycznych. Zob. A. Skarżyńska, L. Goraj, I. Ziętek, Metodologia SGM..., s. 24.

$7 \quad$ Metodyka liczenia nadwyżki bezpośredniej i zasady typologii gospodarstw rolniczych, praca zbiorowa w ramach projektu Phare PL 9607-01-15/22/773, Warszawa 2000, s. 8 i nast. 
go regionu warunkach produkcji. Dla uniknięcia odchyleń wywołanych zmiennością ilościowego oraz wartościowego rozmiaru produkcji związanego z biologicznym ryzykiem produkcji rolnej oraz zmiennością kosztów poniesionych na jej wytworzenie, w wyliczeniach brane są pod uwagę średnie z trzech lat. Z tego właśnie powodu pojęcie nadwyżki bezpośredniej zostało uzupełnione przez określenie standardowa. Standardowe nadwyżki bezpośrednie uaktualniane są co dwa lata i obliczane dla poszczególnych regionów rolniczych określanych jako regiony SGM.

Regiony SGM ustalane są przez poszczególne państwa członkowskie, które dokonują podziału terytorium kraju na jednostki administracyjno-statystyczne ${ }^{8}$. W Polsce wyróżnienie takich jednostek określane jest jako Nomenklatura Jednostek Terytorialnych do Celów Statystycznych - NTS ${ }^{9}$. Nomenklatura opracowana została w oparciu o istniejący zasadniczy trójstopniowy podział kraju na województwa, powiaty i gminy, przy pomocy którego wyodrębnione zostały także dodatkowe poziomy, składające się z jednostek innych niż administracyjne. Wydzielenie regionów SGM wymagało uwzględnienia licznych finansowo-produkcyjnych parametrów oraz ich odchyleń w poszczególnych obszarach ${ }^{10}$. Uwzględnienie tych danych pozwoliło na wyznaczenie spójnych czterech regionów SGM. Podział terytorium Polski na rolnicze regiony SGM oficjalnie zgłoszony został w aneksie do Traktatu o przystąpieniu Rzeczypospolitej Polskiej do Unii Europejskiej, podpisanego w dniu 16 kwietnia 2003 r. w Atenach, a uwzględniony w porządku wspólnotowym na podstawie rozporządzenia Komisji Europejskiej nr 730/20004 z 19 kwietnia 2004 r. zmieniającego dotychczasowy wykaz regionów SGM w Unii Europejskiej ${ }^{11}$. Stosownie do powołanych postanowień wydzielono cztery regiony SGM.

Region PL_A Pomorze i Mazury obejmuje województwa lubuskie, pomorskie, warmińsko-mazurskie i zachodniopomorskie. Region ten charakteryzuje się stosunkowo dużym jak na polskie warunki obszarem gospodarstw rolnych przy jednoczesnej najniższej w kraju intensywności produkcji.

Liczba wydzielonych regionów SGM w krajach członkowskich UE jest zróżnicowana. Przykładowo Niemcy podzielone zostały na 16 regionów, Francja na 22, natomiast Cypr i Litwa ujęły obszar całego kraju jako jeden region SGM.

$9 \quad$ NTS - Nomenklatura Jednostek Terytorialnych do Celów Statystycznych utworzona została rozporządzeniem Rady Ministrów z dnia 13 lipca 2000 r. (Dz.U. Nr 58, poz. 685 ze zm.) stosownie do wymagań wynikających ze Wspólnej Klasyfikacji Jednostek Terytorialnych do Celów Statystycznych ustanowionej rozporządzeniem Parlamentu Europejskiego i Rady (WE) nr 1059/2003 z dnia 26 maja 2003 r. Dz.Urz. UE L 154 z 21.6.2003, s. 1.

Zasadniczymi parametrami stanowiącymi podstawę do wyróżnienia regionów SGM stanowiły: wartość PKB na mieszkańca w 2001 r., udział rolnictwa w tworzeniu PKB w 2001 r., udział trwałych użytków zielonych w użytkach rolnych w 2001 r., średni plon zbóż z lat 1999-2001, średnia roczna produkcja mleka od 1 krowy z lat 1999-2001, średnia powierzchnia użytków rolnych indywidualnych gospodarstw rolnych, średnia liczba krów dojnych w indywidualnych gospodarstwach w latach 1999-2001, średnia liczba trzody w indywidualnych gospodarstwach w latach 1999-2001, Szerzej zob. A. Skarżyńska, L. Goraj, I. Ziętek, Metodologia SGM „2002”..., s. 12 i nast.

11 Commission Regulation No 730/2004 of 19 April 2004 adapting Regulation No 1859/82 concerning the selection of returning holdings by reason of accession of the Czech Republic, Estonia, Cyprus, Latvia, Lithuania, Hungary, Poland, Slovenia, and Slovakia to the European Union. 
Region PL_B Wielkopolska i Śląsk obejmuje województwa dolnośląskie, kujawsko-pomorskie, opolskie i wielkopolskie. Gospodarstwa rolne są tu nieco większe niż średnia w kraju, a produkcja prowadzona jest w sposób bardzo intensywny. W tym regionie występuje najwyższe w kraju zużycie nawozów mineralnych oraz pasz treściwych. Region ten zajmuje pierwsze miejsce pod względem rozmiarów produkcji towarowej, a producenci tego regionu legitymują się najwyższym poziomem kwalifikacji rolniczych.

Region PL_C Mazowsze i Podlasie obejmuje województwa lubelskie, łódzkie, mazowieckie i podlaskie. Jest największy pod względem obszarowym. Średnia wielkość gospodarstwa jest zbliżona do średniej krajowej. Niska jest natomiast intensywność produkcji. Region charakteryzuje się nadto dużą obsadą inwentarza żywego, głównie bydła, ale stada są nieliczne, co obniża efektywność produkcji.

Region PL_D Małopolska i Pogórze obejmuje województwa małopolskie, podkarpackie, śląskie i świętokrzyskie. Pod względem obszaru użytków rolnych jest to region najmniejszy w kraju. Charakteryzuje się największym w kraju rozdrobnieniem agrarnym i nawet przy bardzo wysokim udziale czynników intensyfikujących, skala produkcji pozostaje najniższa w kraju. Warunki produkcyjne sprzyjają produkcji owoców jagodowych (miękkich) i warzyw gruntowych.

Nadwyżki obliczane są odrębnie dla każdego wydzielonego regionu rolniczego. Zestaw nadwyżek bezpośrednich dla całej wspólnoty liczy ponad 120 kategorii działalności, co z jednej strony odzwierciedla zróżnicowanie rolnictwa w krajach Unii Europejskiej, a z drugiej wskazuje, jak wysoki jest poziom szczegółowości prowadzonych badań i analiz, który ma na celu zapewnienie porównywalności gromadzonych danych. Zgromadzone dane stanowią zatem obiektywne kryteria dokonywania klasyfikacji gospodarstw rolnych pod względem wielkości ekonomicznej oraz typu rolniczego.

\subsection{Klasyfikacja według wielkości ekonomicznej gospodarstw rolnych - ESU}

Wielkość ekonomiczna (zwana też żywotnością ekonomiczną) gospodarstwa określana jest za pomocą szczególnego parametru, jakim jest Europejska Jednostka Wielkości - ESU ${ }^{12}$. Wartość jednego ESU odpowiada określonej wartości standardowej nadwyżki bezpośredniej wyrażonej w euro. Jedno ESU odpowiada równowartości 1200 euro. Wielkość ekonomiczna gospodarstwa odpowiada sumie wartości standardowych nadwyżek bezpośrednich wszystkich działalności prowadzonych w gospodarstwie. Procedura określenia wielkości ekonomicznej gospodarstwa rol-

ESU - z ang. European Size Unit. 
nego składa się z rachunkowych przeliczeń dokonywanych w ściśle określonej kolejności.

Procedurę rozpoczyna ustalenie kategorii produkcji prowadzonych w gospodarstwie oraz ustalenie ich rozmiaru wyrażane w hektarach użytków rolnych lub ilości zwierząt. Rozmiar poszczególnych kategorii produkcji należy pomnożyć przez wartość standardowej nadwyżki bezpośredniej. Wielkości SGM podlegają zsumowaniu dla wszystkich działalności, a uzyskany wynik to standardowa nadwyżka bezpośrednia gospodarstwa, z którego pochodzą dane. Nadwyżka wyrażona w złotówkach podlega przeliczeniu na euro według ustalonego, jednolitego przelicznika ${ }^{13}$. Całkowitą standardową nadwyżkę bezpośrednią gospodarstwa rolnego przeliczoną na euro należy wyrazić w ESU poprzez podzielenie ustalonej kwoty standardowej nadwyżki bezpośredniej przez 1200. Otrzymany wynik określa wielkość ekonomiczną gospodarstwa rolnego, która stanowi podstawę do zaliczenia gospodarstwa do jednej z dziesięciu klas wielkości ekonomicznej. Klasy wyróżnione zostały stosownie do ustalonej wielkości ekonomicznej wyrażonej w ESU. Klasy podzielone zostały na grupy. W odniesieniu od grup ustawodawca wspólnotowy kwalifikuje je wielkościowo, przyjmując terminologię od bardzo małych do bardzo dużych. Klasa I to gospodarstwa o wielkości ekonomicznej do 2 ESU. Klasa II obejmuje gospodarstwa liczące od 2 do 4 ESU. Stanowią one grupę gospodarstw określaną jako bardzo małe. Klasa III obejmuje gospodarstwa legitymujące się wielkością ekonomiczną od 4 do 6 ESU, a klasa IV od 6 do 8 ESU. Gospodarstwa te stanowią grupę gospodarstw małych. Klasa V dotyczy wielkości ekonomicznej od 8 do 12 ESU. Klasa VI zaś od 12 - 16 ESU. Stanowią one grupę gospodarstw średnio małych. Klasa VII odnosi się do gospodarstw osiągających wielkość ekonomiczną od 16 do 40 ESU i stanowi grupę gospodarstw średnio dużych. Klasa VIII obejmuje gospodarstwa wykazujące od 40 do 100 ESU, które stanowią grupę gospodarstw dużych. Klasa IX to gospodarstwa o wielkości 100 do 250 ESU, a klasa X dotyczy gospodarstw wykazujących ponad 250 ESU. Ostatnie dwie klasy tworzą grupę gospodarstw bardzo dużych.

\subsection{Klasyfikacja według rolniczych typów gospodarstw rolnych}

Kolejną klasyfikacją dokonywaną na podstawie standardowej nadwyżki bezpośredniej jest typ rolniczy gospodarstwa. Określenie typu uwzględnia udział standardowej nadwyżki bezpośredniej z poszczególnych działalności produkcji roślinnej i zwierzęcej realizowanych w gospodarstwie odpowiednio do ogólnej wartości SGM. Typ rolniczy wyznaczony według wskazanych zasad odzwierciedla system produkcji. Podział obejmuje dziewięć grup - 1. gospodarstwa specjalizujące się w uprawach polowych; 2. gospodarstwa specjalizujące się w uprawach ogrodniczych; 3. gospodarstwa specjalizujące się w uprawach trwałych; 4. gospodarstwa 
specjalizujące się w chowie zwierząt żywionych w systemie wypasowym; 5. gospodarstwa specjalizujące się w chowie zwierząt żywionych paszami treściwymi; 6. gospodarstwa prowadzące różne uprawy; 7. gospodarstwa prowadzące chów różnych zwierząt; 8. gospodarstwa prowadzące różne uprawy i chów różnych zwierząt; 9. gospodarstwa niesklasyfikowane.

W formule ustalania typów rolniczych mają zastosowanie dwie wartości progowe SGM: 1/3 i 2/3. Gospodarstwa zakwalifikowane do typów ogólnych od 1 do 5 określane są jako specjalistyczne. Wartość standardowej nadwyżki bezpośredniej z działalności, na podstawie której zostały zakwalifikowane do konkretnego typu, stanowi więcej niż 2/3 ogólnej wartości SGM. Gospodarstwa zakwalifikowane do typów ogólnych od 6 do 8 prowadzą łącznie produkcję roślinną i zwierzęcą. Wartość SGM z działalności, na podstawie których zostały zakwalifikowane do konkretnych typów jest równa lub mniejsza niż 2/3 ogólnej wartości SGM gospodarstwa. Gospodarstwa, w których udział wartości SGM badanych działalności mieści się w przedziale od 1/3 do 2/3/ ogólnej wartości SGM gospodarstwa, określane są jako dwukierunkowe. Natomiast gospodarstwa, w których udział wartości SGM badanych działalności nie przekraczają 1/3 wartości SGM gospodarstwa, określane są jako mieszane. Typ ogólny 9 to gospodarstwa niesklasyfikowane, obejmujące te gospodarstwa, które nie spełniły warunków do klasyfikacji w typach 1 do 8.

\section{Klasyfikacja gospodarstw rolnych w postanowieniach rozporządzenia Komisji nr 1242/2008}

Dotychczasowa wspólnotowa typologia gospodarstw rolnych stosowana jest w krajach członkowskich UE od przeszło dwudziestu lat. Na przestrzeni tego czasu założenia wspólnej polityki rolnej oraz potrzeby gospodarcze i społeczne związane $\mathrm{z}$ organizacją i funkcjonowaniem gospodarstw rolnych ulegały licznym zmianom i modyfikacjom. Przeto konieczna okazała się zmiana założeń wspólnotowej typologii gospodarstw rolnych, tak by uwzględnić - zalecane według najnowszych założeń wspólnej polityki rolnej - znaczenie funkcji środowiskowych gospodarstw rolnych oraz poszerzanie zakresu działalności pozarolniczych w gospodarstwach rolnych ${ }^{14}$. W konsekwencji przyjęcia nowych założeń także obowiązująca dotychczas jednostka przeliczeniowa ESU i zasady jej ustalania musiały ulec zmianie, tak by nowe kryteria oceny i dokonywana na tej podstawie klasyfikacja gospodarstw uwzględniały założoną wielofunkcyjność rolnictwa oraz jego społeczne zrównoważenie ${ }^{15}$.

A. Liro, Rozwój Obszarów Wiejskich - Integracja ochrony przyrody z polityką rolna, Warszawa 2001, s. 3 i nast. Na gruncie projektów zmian wspólnotowej typologii gospodarstw rolnych propozycje nowych rozwiazań prezentowali: J.S. Zegar, Rachunkowość w rolnictwie postindustrialnym, materiały nie publikowane z międzynarodowej konferencji nt: 80 lat rachunkowości rolnej w Polsce. Warszawa 8 września 2006 r.; A. Woś, J.S. Zegar, Rolnictwo społecznie zrównoważone, Warszawa 2002, s. 9 i nast.; A. Liro: Rozwój Obszarów Wiejskich - Integracja ochrony przyrody z polityką rolna, Warszawa 2001, s. 3 i nast. oraz W. Wilk, Koncepcja wykorzystania danych rachunkowych FADN do ustalenie stopnia zrównoważenia gospodarstw rolnych, (w:) Koncepcja badań nad rol- 
Nowe reguły klasyfikowania gospodarstw rolnych oraz prowadzenia badań dla potrzeb klasyfikacji wyznacza powoływane już rozporządzenie Komisji nr 1242/2008 ustanawiające nową typologię gospodarstw rolnych oraz rozporządzenie Parlamentu Europejskiego i Rady (WE) nr 1166/2008 w sprawie badań struktury gospodarstw rolnych i badania metod produkcji rolnej oraz uchylające rozporządzenie Rady (EWG) nr 571/88 ${ }^{16}$. Zasadnicze zmiany wprowadzone na mocy postanowień powołanych przepisów sprowadzają się do zmiany stosowanego przelicznika (SGM) i jednostki klasyfikacji (ESU) przez wprowadzenie Standardowej Produkcji (SP) wyrażanej w euro, poszerzeniu przedmiotu badań o działalności występujące w gospodarstwach rolnych a dotąd nieuwzględnianych jako element ekonomicznej wartości gospodarstw, a w konsekwencji rozszerzenia dotychczasowej typologii gospodarstw rolnych o kategorię działalności gospodarczej innej niż rolnicza bezpośrednio związana z gospodarstwem.

Nowe regulacje zakładają badanie struktury gospodarstw rolnych. W roku 2010 badanie przeprowadzone ma być w formie spisu, zaś badania w latach 2013 i 2016 mogą być przeprowadzone jako badania reprezentatywne. Państwa członkowskie dla potrzeb typologii mogą wykorzystywać dane pochodzące ze zintegrowanego systemu zarządzania i kontroli przewidzianego rozporządzeniem Rady nr 1782/2003 ${ }^{17}$, systemu identyfikacji i rejestracji bydła, o którym mówi rozporządzenie Parlamentu Europejskiego i Rady nr 1760/2000 ${ }^{18}$ oraz rejestru gospodarstw ekologicznych ustanowionego rozporządzeniem Rady nr 834/200719, a także z innych źródeł administracyjnych, zwłaszcza rejestrów prowadzonych dla potrzeb produkcji rolnej (przykładowo rejestrów roślin genetycznie modyfikowanych). Zakres badań uległ znacznemu poszerzeniu, zwłaszcza przez uwzględnienie realizowanych przez gospodarstwa czynności związanych z ochroną krajobrazu, środowiska, w tym gleby, poprzez nawadniania gruntów. Do zmiennych klasyfikacyjnych zaliczono także dodatkowe działalności zarobkowe osób pracujących w gospodarstwie oraz inne niż rolnicze działalności związane z gospodarstwem ${ }^{20}$. Okresy badań dla potrzeb ustalenia standardowej produkcji (SP) zostały wydłużone do lat pięciu, ale zakładają stałą aktualizacje danych.

nictwem społecznie zrównoważonym. Program wieloletni 2005-2009, IERiGŻ - PIB 2005, nr 11, s. 134-152; E. Majewski, Ekonomiczno-organizacyjne uwarunkowania rozwoju Systemu Integrowanej Produkcji Rolniczej (SIPR) w Polsce, Warszawa 2002, s. 26-27.

16 Rozporządzenie z dnia 19 listopada 2008 r., Dz.Urz. UE L 321 z 1.12.2008, s. 14.

17 Rozporządzenie Rady (WE) nr 1782/2003 z dnia 29 września 2003 r. ustanawiające wspólne zasady dla systemów wsparcia bezpośredniego w ramach wspólnej polityki rolnej i ustanawiające określone systemy wsparcia dla rolników, Dz.Urz. UE L 270 z 21.10.2003, s. 1.

18 Rozporządzenie Parlamentu Europejskiego i Rady (WE) nr 1760/2000 z dnia 17 lipca 2000 ustanawiające system identyfikacji i rejestracji bydła i dotyczące etykietowania wołowiny i produktów z wołowiny, Dz.Urz. UE L 204 z 11.8.2000, s. 1.

19 Rozporządzenie Rady (WE) nr 834/2007 z dnia 28 czerwca 2007 r. w sprawie produkcji ekologicznej produktów rolnych oraz znakowania produktów rolnych i środków spożywczych, Dz.Urz. UE L 189, z 20.7.2007, s. 1. Zob. Załącznik nr III do rozporządzenia nr 1166/2008. 


\subsection{Gospodarstwa rolne według typu rolniczego oraz wielkości ekonomicznej}

Typ rolniczy oraz wielkość ekonomiczną gospodarstwa klasyfikuje się na podstawie kryterium ekonomicznego, jakim jest standardowa produkcja (SP) ustalona dla danego produktu, wytworzonego w określonym regionie produkcyjnym. SP wyrażana jest w euro.

Wyróżnienie typu rolniczego gospodarstwa rolnego dokonywane jest według cech produkcji rolnej oraz udziału dominującej produkcji w standardowej produkcji, przy zachowaniu dotychczasowych progów współczynnika standardowej produkcji na poziomie $2 / 3$ i $1 / 3$. Przepisy wyróżniają trzy podstawowe typy rolnicze - gospodarstwa ogólnego typu rolniczego, gospodarstwa podstawowego typu rolniczego oraz gospodarstwa szczegółowych typów rolniczych ${ }^{21}$. W ramach typów, podobnie jak dotychczas, wyróżnionych zostało dziewięć klas gospodarstw, począwszy od wyspecjalizowanych w uprawach ujętych w klasach 1-3, wyspecjalizowanych w produkcji zwierzęcej w klasach 4-5, przez gospodarstwa mieszane w klasach 68, po gospodarstwa niesklasyfikowane, ujęte jako klasa 9, w których całkowita standardowa produkcja wynosi zero.

Wielkość ekonomiczną gospodarstwa stanowi całkowita standardowa produkcja gospodarstwa wyrażona w euro. Klasyfikacja obejmuje czternaście klas, począwszy od gospodarstw osiągających poniżej 2.000 euro, a skończywszy na gospodarstwach, w których standardowa produkcja jest równa lub wyższa niż 3.000.000 euro $^{22}$.

\subsection{Działalność gospodarcza inna niż rolnicza bezpośrednio związana z gospodarstwem}

Omówienie najnowszej klasyfikacji gospodarstw rolnych według działalności gospodarczej innej niż rolnicza bezpośrednio związana z gospodarstwem rolnym, wymaga zwrócenia uwagi na zmiany w zakresie przedmiotu badań prowadzonych dla potrzeb wspólnotowej typologii, które wywierają skutki wykraczające poza problematykę klasyfikacji ekonomicznej, kształtując zakres pojęcia działalności rolniczej oraz funkcji gospodarstw rolnych.

Zasady, zakres oraz metody badań określiło powoływane już rozporządzenie Parlamentu i Rady nr 1166/2008. Przedmiotem badań jest gospodarstwo rolne zdefiniowane w art. 2 lit. a jako wyodrębniona pod względem technicznym i ekonomiczny jednostka produkcyjna, oddzielnie kierowana oraz prowadząca na terytorium gospodarczym UE działalność rolniczą jako działalność podstawową (dominującą, 
główną w gospodarstwie) lub drugorzędną (uzupełniającą) ${ }^{23}$. Formułując wykaz rodzajów działalności rolniczej w załączniku nr I do rozporządzenia 1166/2008, ustawodawca zastrzegł, że wymienione działalności definiują jednostkę produkcyjną jako gospodarstwo rolne. A zatem określona jednostka produkcyjna jest gospodarstwem rolnym, które podlega wspólnotowej typologii, o ile prowadzi - jako działalność podstawową lub drugorzędną - działalność w zakresie upraw rolnych, chowu i hodowli zwierząt, łowiectwa oraz prowadzenia działalności usługowej wspomagającej rolnictwo i następującej po zbiorach ${ }^{24}$. W gospodarstwie może być nadto prowadzona zarobkowa działalność inna niż rolnicza, ale bezpośrednio związana z gospodarstwem. Działalnością taką jest przetwórstwo produktów rolnych lub drewna, produkcja energii odnawialnej, akwakultura, leśnictwo, turystyka, wynajem pokoi, rękodzieła, a także prace kontraktowe $\mathrm{z}$ wykorzystaniem środków produkcji gospodarstwa oraz inne, które jednak są bezpośrednio związane z gospodarstwem i mają ekonomiczny wpływ na to gospodarstwo, a nadto wykorzystują zasoby lub produkty gospodarstwa. Dochody uzyskiwane $\mathrm{z}$ tego tytułu uwzględniane są przy ustalaniu współczynnika standardowej produkcji ${ }^{25}$. Postępujący proces zmian związany z wdrażaniem rolnictwa zrównoważonego, ekstensyfikacją produkcji, dywersyfikacją działalności spowodował, że rolnicze jednostki produkcyjne podejmują owe inne działalności natury gospodarczej. Udział takich działalności w strukturze gospodarstw wykazuje stałą tendencję wzrostową. W rezultacie ma to wpływ na sposób i zakres prowadzonej działalności rolniczej, a także na poziom osiąganych w gospodarstwie dochodów. Ten stan rzeczy wymagał uwzględnienia przy klasyfikowaniu gospodarstw rolnych. Nowa typologia gospodarstw rolnych uwzględniła zmienną klasyfikacyjną, która odzwierciedlać ma znaczenie działalności gospodarczej innej niż rolnicza, ale związanej z gospodarstwem. Udział takiej działalności w finalnej produkcji szacuje się jako udział obrotu z działalności gospodarczej innej niż rolnicza, związanej bezpośrednio z gospodarstwem w całkowitym obrocie z gospodarstwa, włącznie z dopłatami bezpośrednimi i wyraża procentowo. Odpowiednio do uzyskanego wskaźnika gospodarstwa ujmuje się w trzech klasach. Do klasy I klasyfikuje się gospodarstwa, w których udział działalności innej niż rolnicza waha się od $0 \%$ do $10 \%$; klasa II obejmuje gospodarstwa z udziałem innej działalności gospodarczej powyżej $10 \%$ do $50 \%$, a klasa III od ponad 50\% do poniżej $100 \%$.

Dodatkowo przepis art. 3 ust. 1 rozporządzenia 1166/2008 wymaga, by objęte badaniami gospodarstwo liczyło co najmniej jeden hektar powierzchni użytków rolnych wykorzystywanych do celów rolniczych. Objęcie badaniami gospodarstw o mniejszej powierzchni użytków jest dozwolone, o ile część produkcji z takich gospodarstw przeznaczona jest na sprzedaż (wprowadzona do obrotu) oraz gdy przekraczają ustalone w załączniku nr II do cytowanego rozporządzenia progi fizyczne, dotyczące przede wszystkim obszaru i wielkości produkcji. Załącznik nr I do cytowanego już rozporządzenia nr 1166/2008 zawiera wykaz działalności rolniczej wraz z kodami statystycznymi NACE rev. 2. Są to: uprawy rolne inne niż wieloletnie 01.1; uprawa roślin wieloletnich 01.2; rozmnażanie roślin 01.3; chów i hodowla zwierzat 01.4 ; uprawy rolne połaczone z chowem i hodowla zwierzat (działalność mieszana) 01.5; działalność usługowa wspomagająca rolnictwo i następująca po zbiorach 01.6. Wykaz działalności zawiera załącznik nr III do rozporządzenia 1166/2008 Wykaz cech dla badania struktury gospodarstw rolnych. 


\section{Znaczenie wspólnotowej typologii gospodarstw rolnych}

Wspólnotowa typologia gospodarstw rolnych, parametry stanowiące o kwalifikacji poszczególnych jednostek produkcyjnych, jak i stosowane metody badawcze wywołują skutki daleko wykraczające poza ramy statystyki czy rachunkowości.

Przede wszystkim zwraca uwagę funkcjonalne ujęcie gospodarstwa rolnego. Przepisy regulujące wspólnotową typologię oraz zasady ustalania cech klasyfikacyjnych traktują gospodarstwo jako jednostkę produkcyjną, którą od innych występujących w obrocie gospodarczym odróżnia i jednocześnie definiuje jako gospodarstwo rolne, rodzaj prowadzanej działalności - działalności rolniczej - oraz osiągane z tego tytułu dochody. Zmieniające się założenia wspólnej polityki, zasady oddziaływania na rolnictwo przede wszystkim w ramach wspierania obszarów wiejskich, w których gospodarstwo stanowi integralną część ekosystemu, wymagało uwzględnienia ograniczenia skali produkcji rolnej, dywersyfikacji działalności, podejmowania czynności związanych z ochroną środowiska, krajobrazu czy dziedzictwa kulturowego, a w konsekwencji zmiany czynników kształtujących ekonomiczny status rolniczych jednostek produkcyjnych. W tych właśnie okolicznościach upatrywać należy przyczyn, dla których nowe założenia wspólnotowej typologii gospodarstw rolnych rozbudowały zakres czynników objętych badaniami, poszerzyły istniejącą dotychczas klasyfikację o nową kategorię, a w dotychczas stosowanych rozbudowały klasy i grupy klasyfikacyjne. Podkreślić też należy, że bez względu na dokonywane zmiany profilu produkcji i wynikające stąd czynności prowadzone przez rolne jednostki produkcyjne, pozostają one gospodarstwami rolnymi tylko wówczas, gdy prowadzą choć jedną z działalności rolniczych, nawet jeżeli z tego tytułu uzyskują tylko minimalne dochody. Nadto, działalności gospodarcze inne niż produkcja rolna wymagają, by były prowadzone w związku z zasobami materialnymi gospodarstwa - ziemią, budynkami, budowlami, urządzeniami, maszynami oraz zasobami osobowymi lub z wykorzystaniem produktów pochodzących z gospodarstwa rolnego ${ }^{26}$.

Dalej, podkreślić należy, że z uwagi na zasady stosowania rozporządzeń wspólnotowych, które nie podlegają implementacji, lecz stanowią od daty ich uchwalenia część obowiązującego porządku prawnego poszczególnych państw członkowskich, funkcjonalne zdefiniowanie gospodarstwa rolnego poprzez określenie prowadzonych działalności i źródeł pozyskiwanych stąd dochodów oraz przez wskazanie minimalnych wielkości obszarowych i rozmiaru produkcji, będzie rzutowało na kształtowanie się pojęcia gospodarstwa rolnego i działalności rolniczej dla potrzeb polskiego obrotu towarowego. Przedmiot badań oraz parametry fizyczne, na podstawie których dokonuje się wspólnotowej typologii gospodarstw rolnych stanowić będą kryterium, według którego z ogółu rolnych jednostek gospodarczych odróżnić będzie można towarowe gospodarstwa rolne, które są uczestnikami powszechne- 
go obrotu gospodarczego, od innych jednostek gospodarczych niemających takiego charakteru. Stosownie też do grupy, w której uplasowały się objęte wspólnotową typologią gospodarstwa rolne, dobierane będą instrumenty wsparcia finansowego stosowane w ramach programu rozwoju obszarów wiejskich i innych programów pomocowych. Wielkość ekonomiczna gospodarstw rolnych stanowi tu bowiem istotny element stosowania mechanizmów wspólnej polityki rolnej. Wskazuje na kryterium kwalifikacji jednostki produkcyjnej, jaką jest gospodarstwo rolne dla uzyskania pomocy ze środków unijnych lub też jest celem, które gospodarstwo powinno osiągnąć wskutek uzyskanej pomocy. W Polsce, już w założeniach Planu Rozwoju Obszarów Wiejskich na lata 2004-2006 oraz Sektorowym Programie Operacyjnym, żywotność ekonomiczna gospodarstwa rolnego zdefiniowano jako dolną granicę wielkości ekonomicznej gospodarstwa na poziomie 4 ESU. Powołane dokumenty programowe zakładały, co do zasady, udzielanie wsparcia dla gospodarstw osiągających co najmniej wielkość ekonomiczną 4 ESU. Wyjątkiem była możliwość uzyskania wsparcia dla gospodarstw niskotowarowych ${ }^{27}$, czyli tych, których wielkość ekonomiczna wahała się od 2 do 4 ESU $^{28}$. Wielkość 4 ESU, jako minimalna dla oceny ekonomicznej żywotności gospodarstwa, utrzymana została w Programie Rozwoju Obszarów wiejskich na lata 2007-2013 (PROW 2007-2013) ${ }^{29}$. Badania konkurencyjności polskich gospodarstw, ich zdolności adaptacyjnych, inwestycyjnych, wykorzystania dopłat oraz udziału w rynku wskazują, że najlepsze rokowania w tym zakresie wykazują gospodarstwa osiągające żywotność ekonomiczną na poziomie od 8 od 16 ESU (według nowej typologii mieszczące się w klasach IV i V). Natomiast dla gospodarstw kwalifikowanych w granicach 1 do 4 ESU przy niezmienionych zasadach funkcjonowania, prognozowane jest całkowite zanikanie w przedziale czasu odpowiadającemu jednemu pokoleniu ${ }^{30}$.

Legalna definicja gospodarstwa niskotowarowego zawarta została w rozdziale IX Traktatu Akcesyjnego. Zgodnie z jej brzmieniem, są to takie gospodarstwa, które prowadzą produkcję głównie na własne potrzeby, jak również w niewielkim zakresie sprzedaja część swojej produkcji. Zasady i przesłanki udzielania pomocy dla gospodarstw niskotowarowych były przedmiotem licznych rozstrzygnięć sądów administracyjnych. Zob. m.in.: wyroki: WSA w Warszawie z dnia 27 września 2006 r. sygn. akt IV S.A./Wa 732/06, LEX 256117; WSA w Warszawie z dnia 26 października 2006 r. sygn. akt IV S.A./Wa 1609/06, LEX 284859; WSA w Warszawie z dnia 13 grudnia 2006 r. sygn. akt IV S.A./Wa 1630/06, LEX 329089; NSA z 12 czerwca 2007 r. sygn. akt II GSK 31/07, LEX 345057; NSA z dnia 14 czerwca 2007r. sygn. akt II GSK 51/07 LEX 345087; WSA w Warszawie z dnia 21 marca 2007r. sygn. akt IV S.A./Wa 162/07, LEX 335139; WSA w Warszawie z dnia 3 listopada 2006 r. sygn. akt IV S.A./Wa 1328/06, LEX 329091.

28 Szerzej nt wsparcia dla gospodarstw żywotnych ekonomicznie zob. D. Łobos-Kotowska: Prawne instrumenty wsparcia gospodarstw żywotnych ekonomicznie, Studia luridica Agraria 2007, t. 6, s. 56-70.

29 Rada Ministrów przyjęła projekt PROW 2007-2013 w dniu 1 sierpnia 2006 r. W dniu 11 sierpnia 2006 r. PROW 2007-2013 został przekazany do Komisji Europejskiej celem rozpoczęcia uzgodnień szczegółowych postanowień. W dniu 24 lipca 2007 r. na posiedzeniu Komitetu Rozwoju Obszarów Wiejskich Unii Europejskiej PROW 2007-2013 został zaakceptowany. Normatywne podstawy funkcjonowania PROW 2007-2013 zawarte zostały w ustawie z dnia 7 marca 2007 r. o wspieraniu rozwoju obszarów wiejskich z udziałem środków Europejskiego Funduszu Rolnego na Rzecz Rozwoju Obszarów Wiejskich, Dz.U. Nr 64, poz. 427.

30 Szerzej wyniki badań prezentuje W. Jóźwiak, Polskie gospodarstwa rolne - czy są konkurencyjne dla gospodarstw innych krajów UE?, Biuletyn Informacyjny ARR 2007, nr 3, s. 44-53. Konkluzje zawarte w tekście sa efektem badań nt. Ekonomiczne i społeczne uwarunkowania rozwoju polskiej gospodarki żywnościowej po wstapieniu Polski do Unii Europejskiej, zadanie 4013 - Sytuacja ekonomiczna i aktywność gospodarcza róznych grup polskich gospodarstw rolnych. 
W dalszej kolejności wypada także zasygnalizować, że kryteria stosowane dla badań struktury oraz wspólnotowa kwalifikacja gospodarstw może i powinna być także uwzględniania w założeniach reform, jakie objąć mają polskie rolnictwo, zwłaszcza reformy Kasy Rolniczego Ubezpieczenia Społecznego oraz zasad opodatkowania działalności rolniczej, umożliwiając zróżnicowanie sytuacji prawnej odpowiednio do wielkości ekonomicznej gospodarstwa, rodzaju i rozmiaru działalności oraz źródeł pozyskiwania dochodów.

Uwzględniając zaś kontekst wspólnotowy, podkreślić należy, że typologia gospodarstw rolnych stanowi jednolite i spójne narzędzie systematyki gospodarstw rolnych funkcjonujących na terenie Unii Europejskiej. Ujednolicona klasyfikacja umożliwia wyłonienie reprezentatywnej próby gospodarstw rolnych z danego kraju lub regionu dla potrzeb systemu rachunkowego FADN. Dane gromadzone według założeń wspólnotowej klasyfikacji są wykorzystywane w badaniach i analizach prowadzonych w systemie EUROSTAT, który dostarcza informacji potrzebnych do kreowania i monitorowania instrumentów wspólnej polityki rolnej. Pozwala także na porównanie struktury gospodarstw rolnych i ich sytuacji ekonomicznej między wyróżnionymi klasami wielkości ekonomicznej i typami gospodarstw w kolejnych okresach aktualizacji badań standardowej produkcji w odniesieniu do poszczególnych krajów członkowskich lub regionów produkcyjnych. 


\section{The Community typology of farmsteads - selected issues}

\section{Summary}

The agricultural holdings which are existing in the European Union can be classified according to basic two criteria: economic size and type of farming.

Additional criterion of classification of agricultural holdings is other gainful activity directly related to the holding. Classification of each category is accomplished according to economic criterion. Standard production is main parameter taken in the Community typology.

The Community typology needs to be arranged as homogenous and appropriate instrument in the agricultural holdings in the European Economic Community.

The community typology enables to appoint the representative attempt of agricultural holdings from the given country or the region for the purposes of accounting system FADN.

Collected data according to assumptions of community classification is being used in examinations and analyses conducted in the EUROSTAT system.

It is providing with instruments needed for creating and monitoring for the information of the Common Agricultural Policy. It lets the economic situation also for comparing the agricultural holdings structure among distinguished size classes economic and with types of holdings. It takes place in next periods of the update of inspections of the standard output with reference to individual membership countries or productive regions. 